\title{
Is the Incision Length Really Important in Minimally Invasive Total Hip Replacement Surgery?
}

\author{
Minimal İnvaziv Total Kalça Artroplastisi Cerrahisinde Insizyon Uzunluğu Gerçekten Önemli \\ midir?
}

\author{
(1) Erman Ceyhan ${ }^{1}$, (1) Fatih İnci ${ }^{1}$, (1) Cahit Koçak², (1) İbrahim Alper Yavuz¹, (1) İrem Yıldırım³, (1) Utku Gürhan1 \\ 1 University of Health Sciences Turkey, Ankara City Hospital, Department of Ortopedics and Traumatology, Ankara, Turkey \\ 2 University of Health Sciences Turkey, Bursa Yüksek Ihtisas Training and Research Hospital, Department of Ortopedics and Traumatology \\ ${ }^{3}$ Republic of Turkey Social Security Institution
}

\section{Abstract}

Objectives: The aim of this study was to show the superiority of the minimally invasive techniques over standard techniques and any intraoperative change in incision length.

Materials and Methods: There were 31 patients (8 males, 23 females) operated with the minimally invasive technique, who were defined as group 1 and 42 patients (11 males, 31 females) operated with a standard technique, who were defined as group 2. The hip function was evaluated with Harris Hip Score (HHS), the pain was evaluated with Visual Analogue Scale (VAS) and general physical and mental status with Short Form (SF) - 36. Results: The mean follow-up period was 21.8 months (15-31 months) in group 1 and 58.5 months (42-75 months) in group 2. The duration of the surgery and the duration of hospitalization were longer in group $2(p<0.05)$. Intraoperative blood loss was higher in group 2 ( $<<0.05)$. At the postoperative $3^{\text {rd }}$ month, the SF - 36, VAS and HHS scores in group 1 were significantly better $(p<0.05)$.

Conclusion: Even under favorable conditions, the application of a minimally invasive technique may not give any better cosmetic results for scar tissue than standard techniques.

Key Words: Minimal Invasive Total Hip Replacement, Change in Incision Length, Cosmetic Effect, Standard Incision

\section{Öz}

Amaç: Bu çalışmanın amacı insizyon uzunluğundaki minimal invaziv tekniklerin standart tekniklere göre üstünlüğünü araştırmaktır.

Gereç ve Yöntem: Grup 1 olarak tanımlanan ve minimal invaziv teknikle ameliyat edilen 31 hasta (8 erkek, 23 kadın) ve grup 2 olarak tanımlanan ve standart teknikle ameliyat edilen 42 hasta (11 erkek, 31 kadın) vardı. Kalça fonksiyonu Harris Kalça Puanı (HHS) ile, ağrı Görsel Analog skala (VAS) ve genel fiziksel ve zihinsel durumu Kısa Form - 36 ile değerlendirildi.

Bulgular: Grup 1'de ortalama takip süresi 21,8 ay (15-31 ay) ve grup 2'de 58,5 ay (42-75 ay) idi. Ameliyat süresi ve hastanede yatış süresi grup 2'de daha uzun idi $(p<0,05)$. Intraoperatif kan kaybı grup 2'de yüksekti $(p<0,05)$. Postoperatif 3. ayda grup 1'deki SF - 36, VAS ve HHS skorları anlamlı olarak daha iyi idi $(\mathrm{p}<0,05)$.

Sonuç: Uygun koşullarda bile, minimal invaziv bir tekniğin uygulanması skar dokusu için standart tekniklerden daha iyi kozmetik sonuçlar vermeyebilir.

Anahtar Kelimeler: Minimal İnvaziv Total Kalça Artroplastisi, İnsizyon Uzunluğu Değişimi, Kozmetik Etki, Standart İnsizyon

\section{Introduction}

In total hip arthroplasty, mini-incision or minimally invasive techniques have come into frequent use due to their superiority over standard methods (1-3). The advantages of these techniques are a reduced requirement for postoperative blood transfusion, early mobilization, and regaining of function (2-6). Component malpositioning, a potential increase in complications during

Address for Correspondence/Yazışma Adresi: Spc. Dr. Erman Ceyhan, MD,

University of Health Sciences Turkey, Ankara City Hospital, Department of Ortopedics and Traumatology, Ankara, Turkey

Phone: +90 5057176898 E-mail: ermanceyhanmd@gmail.com ORCID ID: orcid.org/0000-0002-8095-6058

Received/Geliş Tarihi: 15.01.2020 Accepted/Kabul Tarihi: 02.04.2020

๑Copyright 2020 Ankara University Faculty of Medicine

Journal of Ankara University Faculty of Medicine is published by Galenos Publishing House.

All content are under CC BY-NC-ND license. 
surgery, and fixation problems have reported as the main disadvantages of the minimally invasive technique (7-10).

Minimally invasive total hip arthroplasty requires an appropriate surgical set and an experienced surgeon $(1,11,12)$. In these operations, it is more critical to protect the soft tissue from taking damage than to keep the incision length short (12-14). Not using special minimally invasive surgery instruments may lead to complications (1). Proper planning improves minimally invasive hip arthroplasty outcomes in all patients, especially in obese patients.

There are studies in the literature that have compared minimally invasive hip arthroplasty with standard hip arthroplasty $(9,15,16)$. We focused on postoperative results of minimally invasive surgery and standard techniques in our clinic, particularly on any postoperative change to the preoperative incision length and the cosmetic effects of that. This study aimed to show the superiority of minimally invasive techniques over standard techniques and to show any intraoperative change in incision length.

\section{Materials and Methods}

We evaluated the retrospective analysis of prospective data. The study comprised 31 patients (8 male, 23 female) in group 1 who underwent minimally invasive surgery using a lateral incision and 42 patients (11 males, 31 females) in group 2 who underwent surgery with standard techniques. The mean age was 61 years (range: 45-75 years) in group 1 and 63 years (range: 32-71 years) in group 2. There were 26 cases of primary and five secondary coxarthrosis in group 1 and 33 primary and nine secondary coxarthrosis in group 2 (Table 1). Any patients with a Body Mass index of over 30, aged over 75 years, with inflammatory arthritis, having undergone hip surgery previously on the same side or who had infection were excluded from the study.

\begin{tabular}{|c|c|c|c|}
\hline & Group 1 & Group 2 & $\mathrm{p}$ value \\
\hline Number of hips & 31 & 42 & - \\
\hline Gender (M/F) & $8 / 23$ & $11 / 31$ & - \\
\hline $\begin{array}{l}\text { Age } \\
\text { (years) (range) }\end{array}$ & $\begin{array}{l}61 \\
(45-75)\end{array}$ & $\begin{array}{l}63 \\
(32-71)\end{array}$ & $>0.05$ \\
\hline $\begin{array}{l}\text { Body Mass index } \\
\left(\mathrm{kg} / \mathrm{m}^{2}\right) \text { (range) }\end{array}$ & $\begin{array}{l}25.3 \\
(21.4-29.7)\end{array}$ & $\begin{array}{l}26.1 \\
(22.1-29.9)\end{array}$ & $>0.05$ \\
\hline \multicolumn{4}{|l|}{ Preoperative diagnosis } \\
\hline Primer osteoarthritis & 26 & 33 & - \\
\hline $\begin{array}{l}\text { Seconder } \\
\text { osteoarthritis }\end{array}$ & 5 & 9 & - \\
\hline $\begin{array}{l}\text { Follow up } \\
\text { (months) (range) }\end{array}$ & $\begin{array}{l}21.8 \\
(15-31)\end{array}$ & $\begin{array}{l}58.5 \\
(42-75)\end{array}$ & $>0.05$ \\
\hline M: Male, F: Female & & & \\
\hline
\end{tabular}

\section{Preoperative Evaluation}

All patients were evaluated preoperatively for pain using the VAS for general physical and mental status using Short Form 36 (SF-36) and for hip joint function using the Harris Hip score (HHS). Anteroposterior radiographs were taken preoperatively of both hips internally rotated by $15^{\circ}$. Surgical planning was done with a template on the radiograph. At least 12 hours before surgery, venous thrombosis prophylaxis of Enoxaparin 0.6 cc was administered. An intravenous infusion of $5 \mathrm{mg}$ diazepam was administered the night before the operation, and 45 minutes before surgery, $1 \mathrm{gr}$ Cefazolin was given as antibiotic prophylaxis.

\section{Surgical and Anesthetic Procedure}

All operations were performed by the same surgeons (OFO and $\mathrm{AOY}$ ). All procedures were performed using a Bi-Metric porous-coated uncemented prosthesis. The subjects included all patients for primary cementless total hip arthroplasty. Patients were taken into surgery under general or regional anesthesia in a supine position by the same anesthesia team. In both patient groups, $0.03 \mathrm{mg} / \mathrm{kg}$ midazolam IV and one $\mu \mathrm{g} / \mathrm{kg}$ fentanyl IV were applied for sedation. Then, with entry into the spinal space, the spinal anesthesia technique was used with $15 \mathrm{mg}$ $0.5 \%$ heavy bupivacaine. During the operation, $10 \mathrm{~mL} / \mathrm{kg}$ per hour of isotonic fluid was administered and fluid as much as the estimated amount of bleeding was added. Two patients needed general anesthesia, one patient from each group. Before starting the incision, the planned incision length was measured with a sterile ruler (Figure 1). A lateral skin incision was made at the level of the anterior edge of the femur, with two thirds proximal to the tip of the trochanter major and one-third distal. The length of the starting incision was below $10 \mathrm{~cm}$ in the minimally invasive technique and over $10 \mathrm{~cm}$ in the standard technique. In the patients to whom the minimally invasive technique was applied, after opening the iliotibial fascia, the neck was reached from the front of the gluteus medius muscle and tendon fascia lata. Without separating the gluteus medius muscle anterior fibers from the femur, the retraction was achieved using special retractors in a minimally invasive technique (Figure 2). Total hip

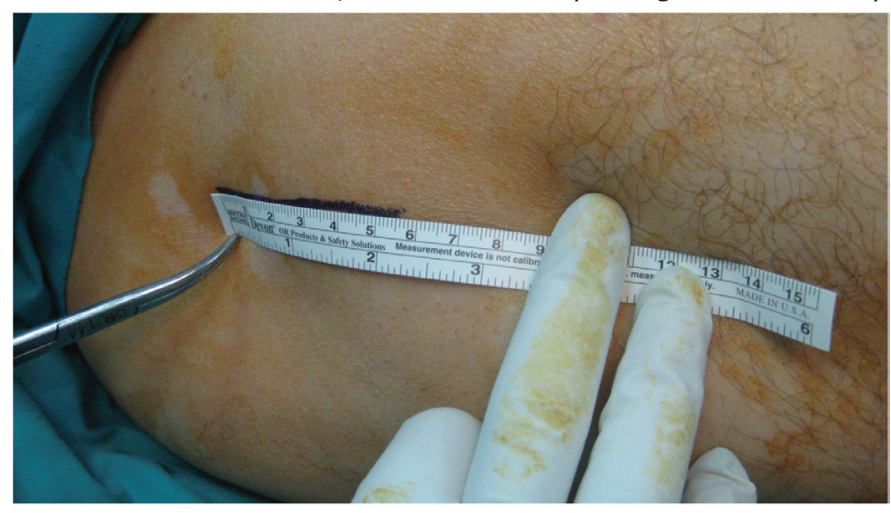

Figure 1: Measurement of incision 
arthroplasty was applied with a classic lateral incision technique (17). The incision length was measured again after the skin had been sutured (Figure 3).

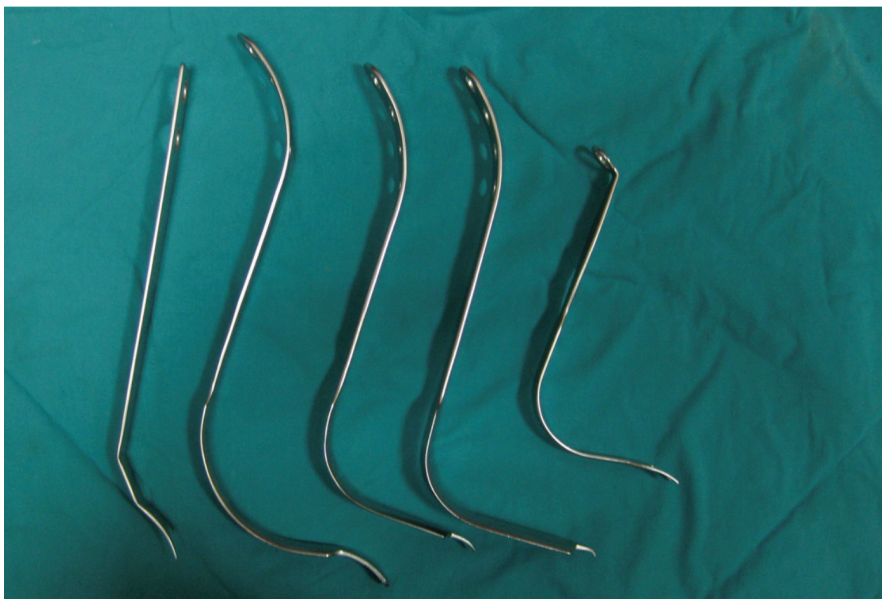

Figure 2: Minimal invasive retractors

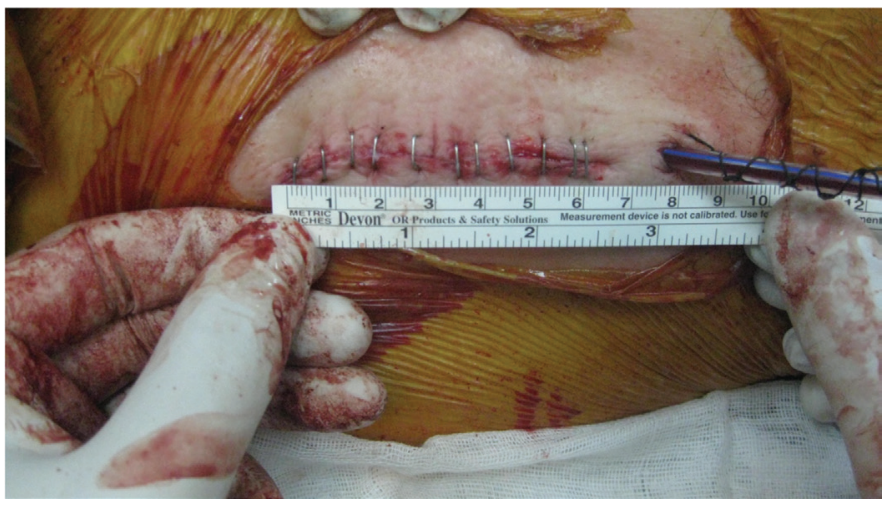

Figure 3: Postoperative measurement of insicion

\section{Postoperative Evaluation}

As venous thromboembolism prophylaxis, 0.6 cc Enoxaparin was administered daily for three weeks. All patients were given medium pressure compression stockings. On the second postoperative day, the drain was removed. Exercises were started on the first postoperative day to strengthen the quadriceps and hip abductors. On the $3^{\text {rd }}$ day, the patients were mobilized with a walking frame partial weight-bearing for up to 6 weeks. After the $6^{\text {th }}$ week, full weight-bearing mobilization continued without a walking frame.

Blood loss, duration of surgery, amount of blood transfusion, length of skin incision recorded intraoperatively. Time of starting mobilization, duration of hospitalization, acetabular cup position, and femoral stem alignment recorded postoperatively.

Radiographic evaluation was made regularly on the first day, the sixth week, the third month, the sixth month, and the $12^{\text {th }}$ month postoperatively by a board-certified orthopedic surgeon (E.C). Follow-up continued beyond one year with radiographs at
6 - month intervals. In the radiographic evaluation, acetabular cup abduction angle, acetabular cup anteversion, femoral component varus-valgus alignment, and findings of femoral and acetabular component loosening were evaluated. Acetabular cup inclination was evaluated by measuring the angle formed at the intersection of the line crossing the acetabular cup superior and inferior surfaces with the inter-teardrop line. Cup anteversion was measured by the Dorr and Wan method. Stem alignment was evaluated with anteroposterior and lateral radiographs.

Stems were accepted as neutral with a varus-valgus angulation of less than $3^{\circ}$ according to the neutral position on the anteroposterior radiograph and anterior-posterior angulation of less than $3^{\circ}$ according to the neutral position on the lateral radiograph. The pain was evaluated with the VAS, functional results with the HHS, and the patient's general quality of life with the SF - 36 tests. These evaluations were applied in the sixth month and the first year postoperatively and 6 - month intervals after the first year. Cosmetic problems related to the incision scar were evaluated with the Fitzpatrick classification and recorded (18). The data were gathered and examined retrospectively.

\section{Statistical Analysis}

Pearson chi-square test and Fisher's exact test were used in the comparison of statistical variables between the two groups. The Kolmogorov-Smirnov normality test was applied to the constant variables. In the comparison of independent two samples between the two groups, the Mann-Whitney U test was used. Friedman variance analysis was applied to compare the VAS, SF-36, and HHS scores within the groups. A value of $p<0.05$ was accepted as statistically significant.

\section{Results}

The mean follow-up period was 21.8 months (15-31 months) in group 1 and 58.5 months (42-75 months) in group 2. There was no significant difference between the groups in terms of age ( $p>0.05$ ). Mean body mass index (BMI) was $25.3 \mathrm{~kg} / \mathrm{m}^{2}$ (range: 21.4-29.7) in group 1 and $26.1 \mathrm{~kg} / \mathrm{m}^{2}$ (range: $22.1-29.9$ ) in group 2. There was no statistical difference between the groups for BMI ( $p>0.05)$.

The mean preoperative hemoglobin values were $13.25 \pm 0.94$ in group 1 and $13.35 \pm 1.50$ in group 2, with no significant difference between the groups ( $p>0.05$ ). The mean postoperative hemoglobin values were $11.01 \pm 1.02$ in group 1 and $9.76 \pm 1.26$ in group 2 . These results were found to be statistically significant $(p<0.05)$. The total erythrocyte suspension given during and after the operation to group 1 was $2.25 \pm 0.92$ Units and to group 2, 4.04 \pm 2.25 Units of blood. The difference between the two groups was statistically significant $(p<0.05)$ (Table 2$)$. 


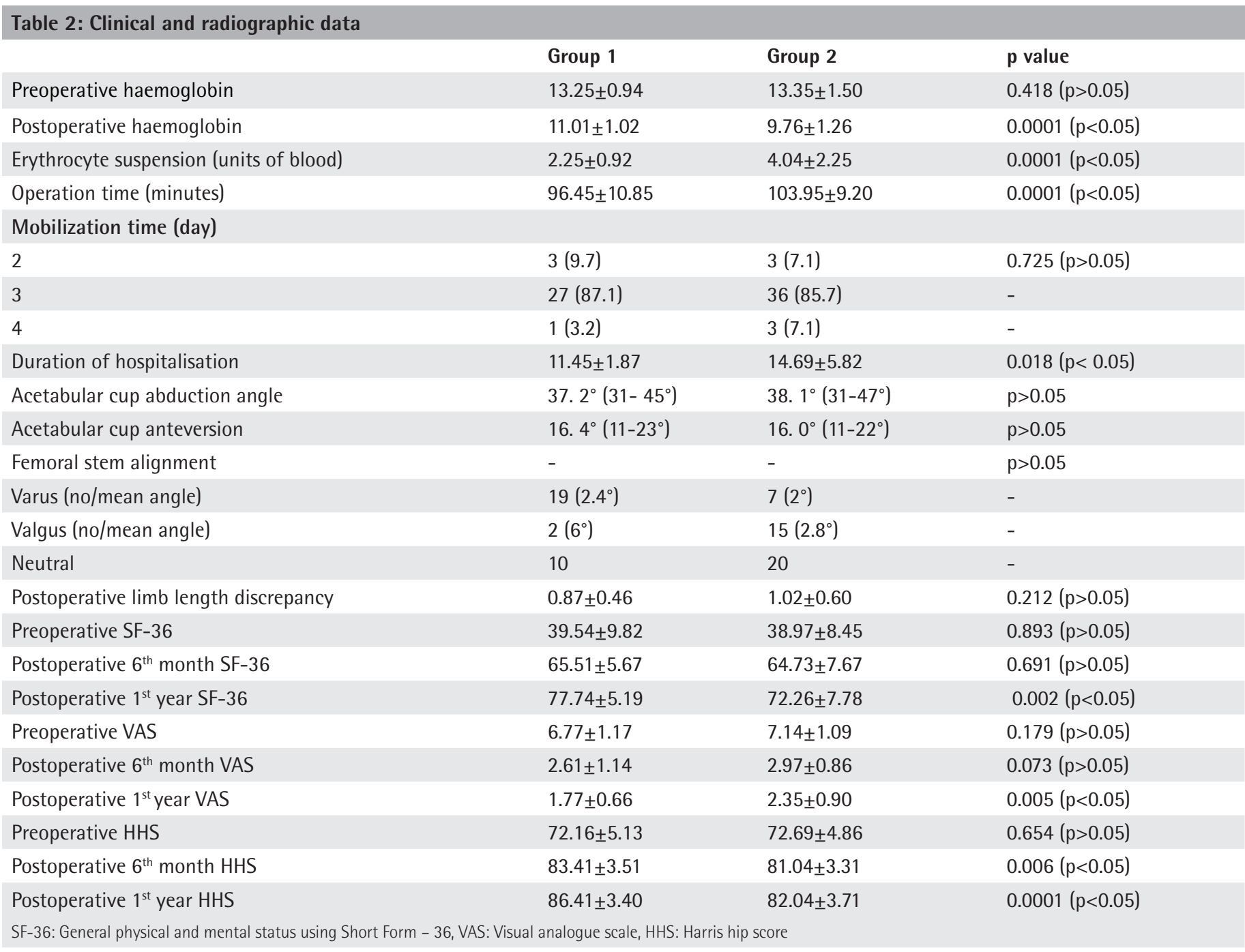

The duration of surgery was longer in group $2(103.95 \pm 9.20$ mins) than in group $1(96.45 \pm 10.85$ mins) $(p<0.05)$. There was no significant difference between the groups for the time of starting mobilization ( $p>0.05$ ). The duration of hospitalization was $11.45 \pm 1.87$ days for group 1 and $14.69 \pm 5.82$ days for group 2. This difference was statistically significant $(p<0.05)$.

The mean acetabular cup abduction angle was measured as $37.2^{\circ}$ (range: $31-45^{\circ}$ ) in group 1 and $38.1^{\circ}$ (range: $31-47^{\circ}$ ) in Group 2. There was no statistically significant difference between the groups $(p>0.05)$. The mean anteversion angle of the acetabular cup was $16.4^{\circ}\left(11-23^{\circ}\right)$ in group 1 and $16.0^{\circ}$ (11$\left.22^{\circ}\right)$ in group $2(p>0.05)$. The femoral stem alignment in the anteroposterior plane for group 1 was two patients with mean $6^{\circ}\left(1-8^{\circ}\right)$ valgus, 19 patients with mean $2.4^{\circ}\left(1-5^{\circ}\right)$ varus, and ten patients centralized. Group 2 was measured as seven patients with mean $2^{\circ}\left(1-4^{\circ}\right)$ varus, 15 patients with mean $2.8^{\circ}\left(1-4^{\circ}\right)$ valgus, and 20 patients centralized. Although two patients in group 1 were seen to be over $5^{\circ}$ valgus, there was no statistically significant difference between the two groups for femoral stem

\begin{tabular}{|c|c|c|}
\hline & & $\mathbf{p}$ \\
\hline Length of the first incision $(\mathrm{cm})$ & $7.4(5.4-9.4)$ & \multirow{2}{*}{$<0.05$} \\
\hline Postoperative length of the incision $(\mathrm{cm})$ & $8.6(5.6-10.8)$ & \\
\hline $10 \mathrm{~cm}>$ (patient no) & 5 & - \\
\hline \multicolumn{3}{|l|}{ Fitzpatrick classification } \\
\hline Group 1 & 2.7 & \multirow[t]{2}{*}{$>0.05$} \\
\hline Group 2 & 2.8 & \\
\hline
\end{tabular}

alignment $(p>0.05)$.

The mean postoperative limb-length discrepancy was 0.87 $\mathrm{cm}$ in group 1 and $1.02 \mathrm{~cm}$ in group 2, with no statistically significant difference $(p>0.05)$. There was no statistically significant difference between the two groups for preoperative VAS, HHS, and SF-36 scores ( $p>0.05)$. There was no significant difference in the SF-36 and VAS scores at the postoperative $6^{\text {th }}$ month ( $p>0.05$ ), but there was a significant improvement in the HHS score of group $1(p<0.05)$. In the postoperative $1^{\text {st }}$ year, the 
SF-36, VAS, and HHS scores in group 1 were significantly better $(p<0.05)$.

The length of the first incision at the beginning of the operation was measured as mean $7.4 \mathrm{~cm}(5.4-9.4 \mathrm{~cm})$, and the incision length measured immediately postoperatively was $8.6 \mathrm{~cm}(5.6-10.8 \mathrm{~cm})$. In five patients to whom the minimally invasive technique was applied, the post-operative incision length was determined to be more than $10 \mathrm{~cm}$. This increase in postoperative incision length was found to be statistically significant $(p<0.05)$. The incision scar was evaluated according to the Fitzpatrick classification system as group 1 mean 2.7 and group 2 mean 2.8. This difference was not significant $(p>0.05)$ (Table 3).

The post-operative hip dislocation was seen in one patient in group 1 and not in group 2, and this difference was not statistically significant $(p>0.05)$. Post-operative wound site infection was observed in three patients in group 1 and four patients in group 2. There was no statistically significant difference in terms of wound site infection ( $p>0.05)$. No findings of acetabular or femoral component loosening were encountered in either group throughout the follow-up period. No femoral fracture was seen in any patient intraoperatively or postoperatively.

\section{Discussion}

The development of minimally invasive techniques in orthopedic surgery, which has hastened recovery and rehabilitation, has inspired the development of minimally invasive techniques in hip arthroplasty. In recent years total hip arthroplasty techniques have been often preferred as they damage soft tissue less, hasten recovery, and gives better cosmetic and rehabilitation results $(2,3)$. Minimally invasive total hip replacement is a surgical approach that gives less damage to skin, muscles, and bone and provides early recovery $(3,6)$.

In the literature related to minimally invasive total hip replacement, few studies are showing an increase in the length of the incision after surgery compared to the preoperative length (16). The current study focused on the change in incision length. Despite appropriate surgical instruments for minimally invasive technique, it was determined that there had been lengthening as the skin deformed during retraction and implantation. In literature, the minimally invasive technique is defined not only by the length of the incision, and if the requirement is stated of trying to keep the incision length below $10 \mathrm{~cm}$ in the application, thus an attempt is made to label the term 'minimally invasive' $(15,19,20)$. In five of the cases in the current study, the incision length on completion of surgery was measured as over $10 \mathrm{~cm}$ in spite of the application of minimally invasive technique. The incision length was not increased during surgery for any reason.
The difference between the incision length at the beginning of surgery and that at the end was of a statistically significant level $(p<0.05)$.

In the cosmetic evaluation of postoperative scar tissue, the Fitzpatrick classification was used (18). This classification allows for the objective and subjective evaluation of the scar tissue color, contours, distortion, and general appearance. In the follow-up period following the patients' recovery from surgery, there was no statistically significant difference between the two groups in the cosmetic evaluation of the incision scar ( $p>0.05$ ).

The duration of surgery may be longer than standard techniques depending on the learning curve and technical equipment $(1,16)$. According to the experience of the surgeon, the duration of surgery is shortened (9). In the current study, the duration of surgery for the minimally invasive total hip replacement group was shorter than that of the group undergoing total hip replacement by standard methods $(p<0.05)$.

Simple cases such as rheumatoid arthritis, osteonecrosis, and primary coxarthrosis without a high body mass index or severely restricted movement should be selected initially for the learning curve of minimally invasive technique. Cases of severe dysplasia, revision surgery, and proximal femoral deformity have been reported as contra-indications for this technique $(1,16,21)$. Similar results have been reported for minimally invasive techniques in obese and thin patients, with no significant difference in the duration of surgery and component position (4). In the current study, there was no significant difference between the two groups in terms of mean BMI ( $p>0.05)$.

It has been reported that as hospitalization is shorter in minimally invasive total hip arthroplasty techniques, hospital infection rates are lower, and it is more cost-effective (1). In the current study, the length of stay in the hospital for group 1 was significantly shorter than for group $2(p<0.05)$.

There is often blood loss in large joint total replacement surgery to an extent that will require transfusion. Following an excessive amount of blood transfusion, various complications may arise. However, in the minimally invasive technique, the mean blood loss, and the need for erythrocyte suspension is lower than in the standard technique (1). In the current study, the mean postoperative hemoglobin value was found to be statistically significantly higher in the minimally invasive group $(p<0.05)$. The need for blood transfusion was also found to be lower both during surgery and in the postoperative follow-up $(p<0.05)$.

Greater improvement has been reported in early postoperative VAS scores and HHS during follow-up of the minimally invasive group compared to the standard technique group and faster rehabilitation and a swifter return to daily activities $(3,12,22-$ 24). In the current study, standard postoperative pain control 
was applied to both groups. A significant improvement was seen in postoperative VAS and HHS scores in the minimally invasive group compared to the standard group. When the general postoperative quality of life and health status were evaluated, the SF-36 score of the minimally invasive group was again determined as higher than the standard group $(p<0.05)$.

Acetabular cup anteversion of between 10 and $20^{\circ}$, acetabular cup abduction angle of between 30 and $50^{\circ}$, and the femoral stem position below $5^{\circ}$ are the optimum values aimed for during surgery (25). In the current study, as the acetabular cup abduction angle and the acetabular inclination angle were within normal limits, no difference was determined between the two groups ( $p>0.05$ ). In two patients in group 1, the femoral stem position was determined to be above $5^{\circ}$ valgus but the difference between the two groups was not statistically significant $(p>0.05)$.

That limb length discrepancy may develop following total or partial hip replacement has been reported in literature (2628). Studies conducted on minimally invasive techniques have not shown this situation $(21,29)$. In the current study, a lower limb length discrepancy, which would affect functions, did not develop in either group ( $p>0.05)$.

When the complication rates were evaluated of the patients in the current study, hip dislocation and wound site infection were encountered. It has been reported in the literature that postoperative hip dislocation occurs more often in a minimally invasive group (30). In the current study, postoperative hip dislocation was seen in one patient in the minimally invasive group and not in the standard group. This difference was not statistically significant $(p>0.05)$. There was no difference between the groups in respect of wound site infection ( $p>0.05)$.

The limitations of this study are that the follow-up period was short, and the length of follow-up was different for the two groups. A longer follow-period may better determine the rates of success between the two groups. The follow-up period of group 1 was shorter than group 2, and this may be an obstacle to the final comparison of the final results of patients. There is a need for a longer follow-up period, particularly for the minimally invasive group.

\section{Conclusion}

Although minimally invasive total hip replacement technique is defined by the length of the incision at the beginning of the operation, the postoperative size of the incision may reach that of a standard hip arthroplasty incision due to retraction and implantation procedures. This condition shows that it is incorrect to name the technique based only on the length of the incision. If the evaluation is to be made according to the length of the incision, it would be more appropriate to measure after skin suturing postoperatively. Even under favorable conditions, the application of a minimally invasive technique may not give any better cosmetic results for scar tissue than standard techniques.

\section{Ethics}

Ethics Committee Approval: Retrospective study.

Informed Consent: Retrospective study.

Peer-review: Externally and internally peer-reviewed.

\section{Authorship Contributions}

Surgical and Medical Practices: E.C., F.I., C.K., I.A.Y., U.G., Concept: E.C., F.I., C.K., I.A.Y., U.G., I.Y., Design: E.C., F.I., C.K., I.A.Y., U.G., I.Y., Data Collection or Processing: E.C., F.I., C.K., I.A.Y., U.G., I.Y., Analysis or Interpretation: E.C., F.I., C.K., I.A.Y., U.G., I.Y., Literature Search: E.C., F.I. C.K., I.A.Y., U.G., I.Y., Writing: E.C., F.I., C.K., I.A.Y., U.G., I.Y.

Conflict of Interest: Each author certifies that he or she has no commercial associations that might pose a conflict of interest in connection with the submitted article.

Financial Disclosure: The authors have not received any funding related to this study.

\section{References}

1. Howell JR, Garbuz DS, Duncan CP. Minimally invasive hip replacement: rationale, applied anatomy, and instrumentation. Orthop Clin North Am. 2004;35:107-118.

2. Lin $\mathrm{DH}$, Jan $\mathrm{MH}$, Liu TK, et al. Effects of anterolateral minimally invasive surgery in total hip arthroplasty on hip muscle strength, walking speed, and functional score. J Arthroplasty. 2007;22:1187-1192.

3. Dorr LD, Maheshwari AV, Long WT, et al. Early pain relief and function after posterior minimally invasive and conventional total hip arthroplasty. A prospective, randomized, blinded study. J Bone Joint Surg Am. 2007;89:11531160.

4. Chimento GF, Pavone V, Sharrock N, et al. Minimally invasive total hip arthroplasty: a prospective randomized study. J Arthroplasty. 2005;20:139144.

5. Meneghini RM, Smits SA. Early discharge and recovery with three minimally invasive total hip arthroplasty approaches: a preliminary study. Clin Orthop Relat Res. 2009;467:1431-1437.

6. Mears DC, Mears SC, Chelly JE, et al. THA with a minimally invasive technique, multi-modal anesthesia, and home rehabilitation: factors associated with early discharge? Clin Orthop Relat Res. 2009;467:1412-1417.

7. Bal BS, Haltom D, Aleto $T$, et al. Early complications of primary total hip replacement performed with a two-incision minimally invasive technique. J Bone Joint Surg Am. 2005;87:2432-2438.

8. Fehring TK, Mason JB. Catastrophic complications of minimally invasive hip surgery: a series of three cases. J Bone Joint Surg Am. 2005;87:711-714.

9. Kim YH. Comparison of primary total hip arthroplasties performed with a minimally invasive technique or a Standard technique: a prospective and randomized study. J Arthroplasty. 2006;21:1092-1098.

10. Graw BP, Woolson ST, Huddleston HG, et al. Minimal incision surgery as a risk factor for early failure of total hip arthroplasty. Clin Orthop Relat Res. 2010;468:2372-2376.

11. Archibeck MJ, White RE Jr. Learning curve for the two incision total hip replacement. Clin Orthop Relat Res. 2004;429:232-238.

12. Khan RJ, Fick $D$, Khoo $P$, et al. Less invasive total hip arthroplasty: description of a new technique. J Arthroplasty. 2006;21:1038-1046. 
13. Mardones R, Pagnano MW, Nemanich JP, et al. The Frank Stinchfield Award: muscle damage after total hip arthroplasty done with the two-incision and mini-posterior techniques. Clin Orthop Relat Res. 2005;441:63-67.

14. Ciminiello M, Parvizi J, Sharkey PF, et al. Total hip arthroplasty: is small incision better? J Arthroplasty. 2006;21:484-488.

15. Pilot $P$, Kerens $B$, Draijer $W F$, et al. Is minimally invasive surgery less invasive in total hip replacement? A pilot study. Injury. 2006;37:17-23.

16. Goosen JH, Kollen BJ, Castelein RM, et al. Minimally invasive versus classic procedures in total hip arthroplasty: a double-blind randomized controlled trial. Clin Orthop Relat Res. 2011;469:200-208.

17. William M. Mihalko, Mark J. Anders, Quanjun Cui, Thomas Brown, Khaled Saleh. Orthopaedic Surgical Approaches. In: Miller M D (ed). Hip and Pelvis, 1st ed. Saunders, Philadelphia, 2008; p. 395-401.

18. Fitzpatrick TB. The validity and practicality of sun-reactive skin types I through VI. Arch Dermatol. 1988;124:869-871.

19. Shitama $T$, Kiyama $T$, Naito $M$, et al. Minimally invasive versus conventional exposure for total hip arthroplasty: a systematic review and meta-analysis of clinical and radiological outcomes. Int Orthop. 2009;33:1543-1547.

20. Smith TO, Blake $V_{1}$ Hing CB. Which is more invasive-mini versus standard incisions in total hip arthroplasty? Int Orthop. 2011;35:173-184.

21. Pflüger G, Junk-Jantsch S, Schöll V. Minimally invasive total hip replacement via the anterolateral approach in the supine position. Int Orthop. 2007;31:711.
22. DiGioia AM, Plakseychuk AY, Levison TJ, et al. Mini-incision technique for total hip arthroplasty with navigation. J Arthroplasty. 2003;18:123-128.

23. Dutka J, Sosin P, Libura M, et al. Total hip arthroplasty through a minimally invasive lateral approach-our experience and early results. Orthop Traumatol Rehab. 2007;9:39-45.

24. Goebel S, Steinert AF, Schillinger J, et al. Reduced postoperative pain in total hip arthroplasty after minimal-invasive anterior approach. Int Orthop. 2012;36:491-498.

25. Lewinnek GE, Lewis JL, Tarr R. Dislocation after total hip replacement arthroplasties. J Bone Joint Surg. 1978;60:217.

26. DeWal H, Su E, DiCesare PE. Instability following total hip arthroplasty. Am J Orthop. 2003;32:377-382.

27. Padgett $D E$, Warashina $H$. The unstable total hip replacement. Clin Orthop Relat Res. 2004;420:72-79.

28. Robbins GM, Masri BA, Garbuz DS, et al. Treatment of hip instability. Orthop Clin North Am. 2001;32:593-610.

29. Siguier T, Siguier M, Bertrand B. Mini-incision anterior approach does not increase dislocation rate. Clin Orthop Relat Res. 2004;426:162-173.

30. Cheng T, Feng JG, Liu T, et al. Minimally invasive total hip arthroplasty: a systematic review. Int Orthop. 2009;33:1473-1481. 